\section{Anti-Ku antibodies: important points to consider}

With interest, we read the recent article by Ogawa-Momohara $e t$ $a l^{1}$ which reports the clinical phenotype of patients with anti-Ku autoantibodies and conclude that systemic lupus erythematosus (SLE) and myositis overlap is rare in patients with this antibody reactivity. $\mathrm{Ku}$ is a well-known protein heterodimer comprised of 70 and $80 \mathrm{kDa}$ subunits and is best-known for its central role in binding to DNA and the double-strand break DNA repair pathway in mammals. ${ }^{2}$

There are several challenges when describing the clinical phenotype of patients with anti-Ku antibodies. First, as noted above, $\mathrm{Ku}$ is a DNA-binding protein. Consequently, it is difficult but imperative to confirm that patients who test positive for anti-Ku antibodies truly have anti-Ku antibodies, or if the reactivity is caused by antibodies to dsDNA or DNA-binding proteins that are complexed with dsDNA/dsDNA-binding proteins in the serum of patients that then secondarily bind to $\mathrm{Ku}$ or dsDNA/dsDNA-binding proteins in an immunoassay (figure 1). In this context, Reeves et $a l^{3}$ demonstrated that anti-Ku reactivity of certain sera as detected by enzyme linked immunoassay Intenrational consensus on antinuclear antibody (ANA) pattern (ELISA) disappeared when the $\mathrm{Ku}$ antigen was dissociated from DNA after washing with $0.5 \mathrm{M}$ or higher $\mathrm{NaCl}$ buffer, indicating that the reactivity of these sera was via binding of DNA and DNA-binding proteins to Ku. Interaction of various dsDNA-binding proteins complexed with $\mathrm{Ku}$ was also reported. ${ }^{4}$ Thus, an analytically false positive anti-Ku ELISA result can be observed if DNA and other DNA-binding proteins are binding to $\mathrm{Ku}$ on the ELISA plate. The same concept applies to other solid phase immunoassays for the detection of anti-Ku antibodies, such as line immunoassays, which are commonly used in clinical laboratory practice. Noteworthy, a similar challenge also exists for anti-Scl-70/topoisomerase I antibodies, a marker that is considered specific for systemic sclerosis, but depending on the assay is also detected in patients with SLE. ${ }^{5}$ Although known for decades, very little data are available on the standardisation of anti-Ku antibodies. In a recent study, a kappa agreement of 0.86 (95\% CI 0.57 to 1.00 ) was found indicating weak-to-perfect agreement. ${ }^{67}$

In addition, if patients are preselected based on HEp-2 indirect immunofluorescence (IIF) patterns, a potential exclusion bias is introduced (figure 2). In the correspondence by OgawaMomohara $e t ~ a l,{ }^{1}$ samples were preselected based on the HEp-2 IIF pattern that has been historically associated with anti-Ku antibodies (ICAP nomenclature AC-04; www.anapatterns.org). ${ }^{8}$ This approach introduces a potential bias because patients with SLE frequently express many autoantibodies ${ }^{9}$ and sera accompanied by mixed HEp-2 IIF patterns are very common and presumably were excluded in this study. Therefore, the conclusion that overlap syndrome in anti-Ku-positive patients is rare might not reflect the entire picture. In our experience, anti-Ku antibodies are frequently found in SLE patients potentially associated with overlap features of a myopathy. ${ }^{10}$ Similarly, anti-Ku antibodies are known as autoantibodies that mark the overlap between myositis and systemic sclerosis. ${ }^{11}$

The observation that a significant portion of anti-Ku-positive patients also exhibit anti-dsDNA antibodies is complicated by the known variability between anti-dsDNA assays. ${ }^{12}$ In the correspondence by Ogawa-Momohara et al, ${ }^{1}$ no information is

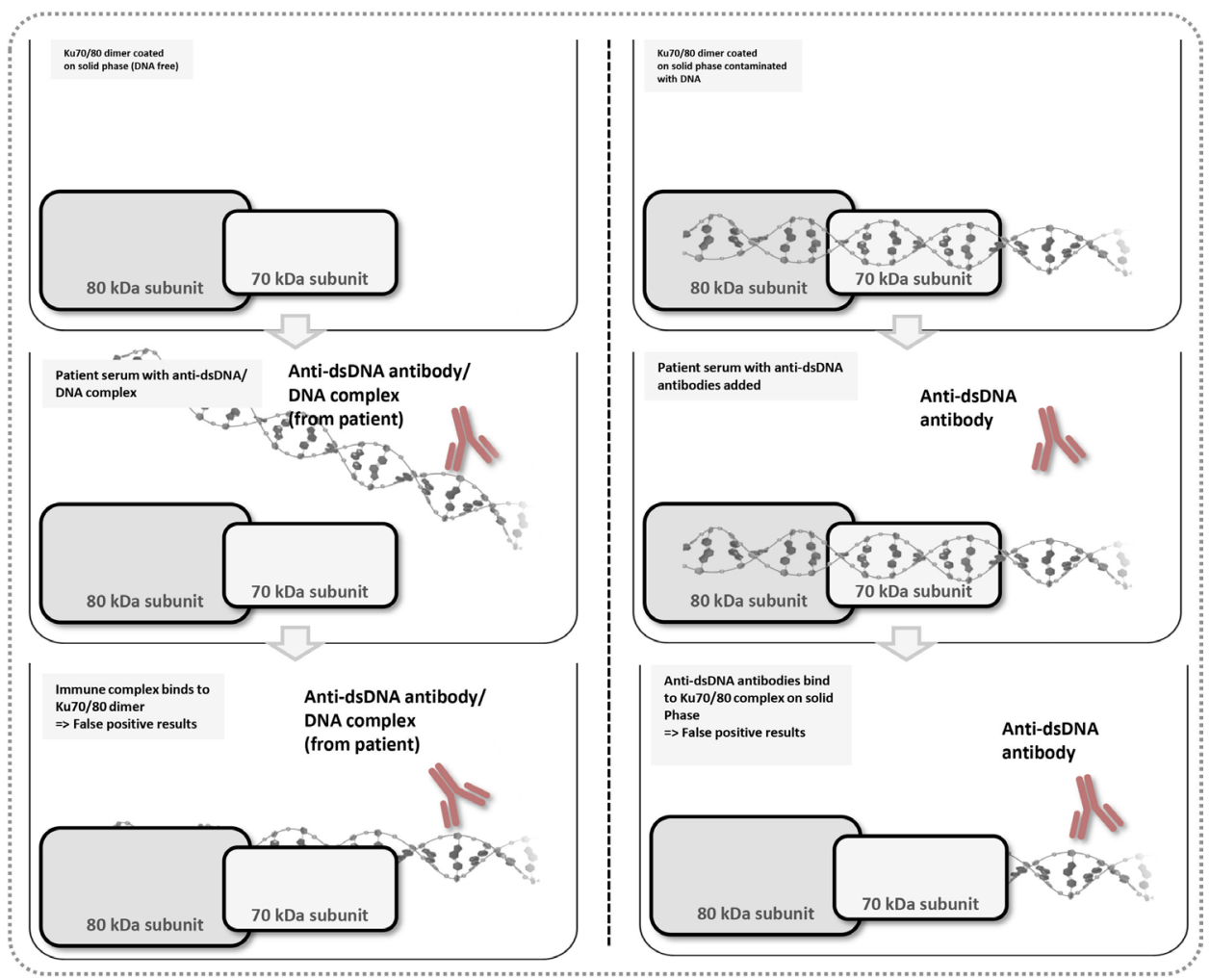

Figure 1 Potential reactivity of anti-dsDNA antibodies in anti-Ku antibody assays. The Ku70/80 heterodimer exhibits dsDNA binding capacities. Consequently, if the antigen used in the Ku assay contains dsDNA, anti-dsDNA antibodies can also bind directly to the Ku70/80-dsDNA complex on the solid phase. In addition, anti-dsDNA/dsDNA complexes that might be present in the sera of patients with autoimmune diseases can generate a positive test result. In addition, other DNA-binding proteins can bind to DNA or the Ku70/80-DNA complex and also serve as autoantigenic targets (not shown for simplicity). 


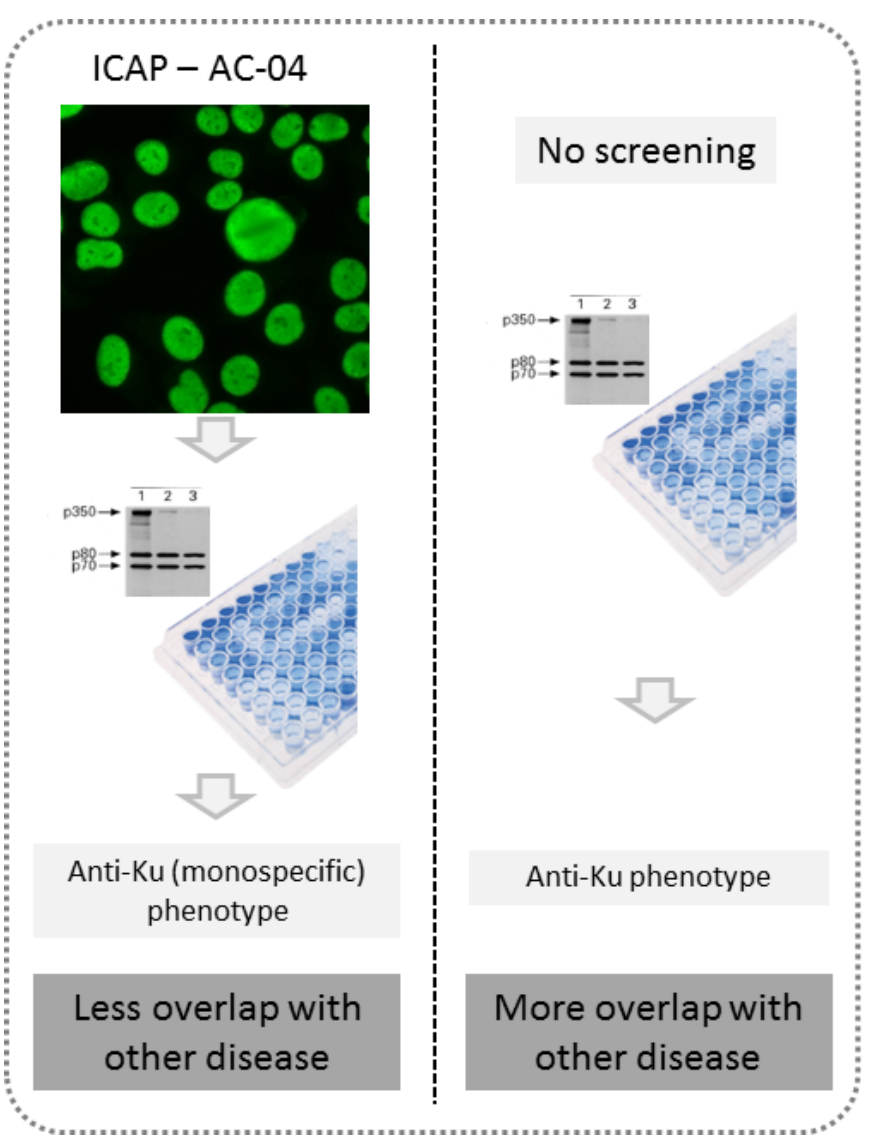

Figure 2 Potential selection bias based on the HEp-2 indirect immunofluorescence (IIF) pattern. The ICAP AC-04 IIF pattern which can be related to anti-Ku antibodies is characterised by fine tiny speckles throughout the nucleoplasm. The nucleoli may or may not be stained. The chromatin mass of mitotic cells (metaphase, anaphase and telophase) is not stained. According to ICAP, other autoantibodies, such as SS-A/Ro60, SS-B/La, Mi-2, TIF1 $\gamma$ and TIF1 $\beta$, can produce a similar IIF pattern. In addition, autoantibodies, such as anti-dsDNA or anti-chromatin antibodies, can mask or confuse the ICAP AC-4 pattern potentially leading to the selection of mostly monospecific anti-Ku antibodies that might not show overlap features.

provided on the methods used for the detection of anti-dsDNA and anti-ssDNA antibodies. Therefore, the interpretation of the results in this study is difficult. Unexpectedly, anti-dsDNA reactivity was found predominantly in myositis and not in SLE patients. Noteworthy, recently a novel standard for anti-dsDNA antibodies has been developed and characterised which interestingly also seems to contain anti-Ku reactivity. ${ }^{13}$ However, studies are pending to ensure that the new anti-dsDNA standard truly contains antibodies to the $\mathrm{Ku} 70 / 80$ heterodimeric complex and not only high levels of anti-dsDNA antibodies or immune complexes that generate positivity in anti-Ku immunoassays. This may or may not represent a link to the two different clusters of anti-Ku antibodies that have been described and also controversially discussed. ${ }^{14-18}$

To conclude, we emphasise that defining the clinical phenotype associated with anti-Ku antibodies is challenging and should be based on a systemic study considering all the aforementioned points raised. In particular, selection of serum samples based on a HEp-2 IIF staining pattern does not capture the full spectrum of the clinical associations of this interesting autoantibody.

Michael Mahler $\odot{ }^{1}{ }^{1}$ Minoru Satoh, ${ }^{2}$ Marvin J Fritzler ${ }^{3}$
${ }^{1}$ Research, Inova Diagnostics, San Diego, California, USA

${ }^{2}$ Department of Clinical Nursing, University of Occupational and Environmental Health, Kitakyushu, Japan

${ }^{3}$ Medicine, Health Sciences Centre, Calgary, Alberta, Canada

Correspondence to Dr Michael Mahler, Research, INOVA Diagnostics, San Diego, CA 32131-1638, USA; mmahler@inovadx.com

Contributors All the authors contributed to the generation of the manuscript. MM drafted the manuscript, coordinated revisions and generated figures. MS provided insights into the cross-reactivity of interference between anti-Ku and anti-dsDNA antibodies. MJF revised the manuscript and provided details around HEp-2 pattern and potential bias for the definition of the clinical phenotype.

Competing interests $\mathrm{MM}$ is an employee of Inova Diagnostics, a company commercialising antibody assays. MJF is a consultant to Inova Diagnostics (San Diego, California, USA) and Werfen International (Barcelona, Spain). No products of Inova Diagnostics are being discussed in the manuscript.

Patient consent for publication Not required.

Provenance and peer review Not commissioned; internally peer reviewed.

(c) Author(s) (or their employer(s)) 2019. No commercial re-use. See rights and permissions. Published by BMJ.

\section{Check for updates}

To cite Mahler M, Satoh M, Fritzler MJ. Ann Rheum Dis Epub ahead of print: [please include Day Month Year]. doi:10.1136/annrheumdis-2019-216535

Received 24 October 2019

Revised 29 October 2019

Accepted 1 November 2019

\section{S Linked}

- http://dx.doi.org/10.1136/annrheumdis-2019-216595

Ann Rheum Dis 2019;0:1-3. doi:10.1136/annrheumdis-2019-216535

ORCID iD

Michael Mahler http://orcid.org/0000-0002-7919-0948

\section{REFERENCES}

1 Ogawa-Momohara M, Muro Y, Akiyama M. Overlap of systemic lupus erythematosus and myositis is rare in anti-Ku antibody-positive patients. Ann Rheum Dis 2019 doi:10.1136/annrheumdis-2019-216375. [Epub ahead of print: 11 Oct 2019].

2 Fell VL, Schild-Poulter C. The Ku heterodimer: function in DNA repair and beyond. Mutat Res Rev Mutat Res 2015;763:15-29.

3 Reeves WH, Satoh M, Wang J, et al. Systemic lupus erythematosus. antibodies to DNA DNA-binding proteins, and histones. Rheum Dis Clin North Am 1994;20:1-28.

4 Satoh M, Ajmani AK, Stojanov L, et al. Autoantibodies that stabilize the molecular interaction of Ku antigen with DNA-dependent protein kinase catalytic subunit. Clin Exp Immunol 1996;105:460-7

5 Mahler M, Silverman ED, Schulte-Pelkum J, et al. Anti-Scl-70 (topo-I) antibodies in SLE: myth or reality? Autoimmun Rev 2010;9:756-60.

6 Mahler M, Vulsteke J-B, Bossuyt X, et al. Standardisation of myositis-specific antibodies: where are we today? Ann Rheum Dis 2019. doi:10.1136/ annrheumdis-2019-216003. [Epub ahead of print: 3 Aug 2019].

7 Espinosa-Ortega F, Holmqvist M, Alexanderson H, et al. Comparison of autoantibody specificities tested by a line blot assay and immunoprecipitation-based algorithm in patients with idiopathic inflammatory myopathies. Ann Rheum Dis 2019;78:858-60.

8 Damoiseaux J, Andrade LEC, Carballo OG, et al. Clinical relevance of HEp-2 indirect immunofluorescent patterns: the International Consensus on ANA patterns (ICAP) perspective. Ann Rheum Dis 2019;78:879-89.

9 Yaniv G, Twig G, Shor DB-A, et al. A volcanic explosion of autoantibodies in systemic lupus erythematosus: a diversity of 180 different antibodies found in SLE patients. Autoimmun Rev 2015;14:75-9.

10 Mahler M, Swart A, Wu J, et al. Clinical and serological associations of autoantibodies to the Ku70/Ku80 heterodimer determined by a novel chemiluminescent immunoassay. Lupus 2016:25:889-96.

11 Kaji K, Fertig N, Medsger TA, et al. Autoantibodies to RuvBL1 and RuvBL2: a novel systemic sclerosis-related antibody associated with diffuse cutaneous and skeletal muscle involvement. Arthritis Care Res 2014;66:575-84

12 Mummert E, Fritzler MJ, Sjöwall C, et al. The clinical utility of anti-double-stranded DNA antibodies and the challenges of their determination. J Immunol Methods 2018;459:11-19.

13 Fox BJ, Hockley J, Rigsby P, et al. A WHO reference reagent for lupus (anti-dsDNA) antibodies: international collaborative study to evaluate a candidate preparation. Ann 
Rheum Dis 2019. doi:10.1136/annrheumdis-2019-215845. [Epub ahead of print: 5 Sep 2019].

14 Spielmann L, Nespola B, Séverac F, et al. Anti-Ku syndrome with elevated CK and antiKu syndrome with anti-dsDNA are two distinct entities with different outcomes. Ann Rheum Dis 2019;78:1101-6.

15 Spielmann L, Séverac F, Meyer A. The heart of anti-Ku related disease: extensive review and meta-analysis. Response to: 'Anti-Ku syndrome with elevated CK: association with myocardial involvement in systemic sclerosis' by Campochiaro et al. Ann Rheum Dis 2019. doi:10.1136/annrheumdis-2019-216095. [Epub ahead of print: 20 Sep 2019].
16 Mahler M, Rossin B, Kubassova O. Augmented versus artificial intelligence for stratification of patients with myositis. Ann Rheum Dis 2019. doi:10.1136/ annrheumdis-2019-216000. [Epub ahead of print: 30 Jul 2019].

17 Pinal-Fernandez I, Mammen AL. On using machine learning algorithms to define clinically meaningful patient subgroups. Ann Rheum Dis 2019. doi:10.1136/ annrheumdis-2019-215852. [Epub ahead of print: 21 Jun 2019].

18 Meyer A, Spielmann L, Séverac F. Artificial intelligence should always be guided by human intelligence. Response to 'Augmented vs. artificial intelligence for stratification of patients with myositis' by Mahler et al. Ann Rheum Dis 2019. doi:10.1136/ annrheumdis-2019-216014. [Epub ahead of print: 30 Jul 2019]. 